\title{
A RENAISSANCE OF THE DOCTRINE OF REBUS SIC STANTIBUS?
}

\author{
JULiAn KulAGA*
}

\begin{abstract}
Once the 'popular plaything of Realpolitiker' the doctrine of rebus sic stantibus post the 1969 VCLT is often described as an objective rule by which, on grounds of equity and justice, a fundamental change of circumstances may be invoked as a ground for termination of a treaty. Yet recent practice from some States suggests that it is returning with a new livery. They point to an understanding that is premised on vital State interests - a view popular among scholars such as Erich Kaufmann at the beginning of the last century.
\end{abstract}

Keywords: public international law, law of treaties, Vienna Convention on the Law of Treaties, clausula rebus sic stantibus, fundamental change of circumstances, vital interests, fundamental rights of States, legal practice.

\section{INTRODUCTION}

'Circumstances alter cases'. Use of this famous proverb can be traced back as far as the seventeenth century writings of the English literary critic and historian Thomas Rymer. ${ }^{1}$ Behind it lies the idea that what ought to be done in a given case may at times depend on the surrounding circumstances. Accordingly, when circumstances change a reassessment of the approach to be pursued may be justified. It is an idea that has also found expression in international law. Article 62 of the Vienna Convention on the Law of Treaties (VCLT), ${ }^{2}$ which is considered to represent in many respects customary international law, ${ }^{3}$ codifies a doctrine that in exceptional cases allows for the termination or

* Research and teaching assistant at the Chair for Public Law and Public International Law, Humboldt University of Berlin, Prof. Dr. Georg Nolte and associated researcher at the Berlin/ Potsdam research group 'The International Rule of Law - Rise or Decline?', julian.kulaga@rewi. hu-berlin.de. The author would like to thank Janina Barkholdt and Campbell McLachlan for their most valuable feedback and comments on earlier drafts of this article. Any errors remain the author's sole responsibility.

1 J Speake, Oxford Dictionary of Proverbs (6th edn, Oxford University Press 2015) 52; T Rymer, The Tragedies of the Last Age (1677) 117-8.

2 (concluded 23 May 1969, entered into force 27 January 1980) 1155 UNTS 331.

3 Fisheries Jurisdiction (United Kingdom v Iceland) (Jurisdiction of the Court: Judgment) [1973] ICJ Rep 3, 19 [36]; Gabčikovo-Nagymaros Project (Hungary/Slovakia) (Judgment) [1997] ICJ Rep 7, 38 [46]; 62 [99]; Case C-162/96 Racke v Hauptzollamt Mainz [1998] ECR I03655 , para 53 . 
suspension of treaties on grounds of a fundamental change of circumstances: the doctrine of rebus sic stantibus (the doctrine). When drafting what would later become Article 62 VCLT, the International Law Commission (ILC) intended the doctrine to be 'an objective rule of law by which, on grounds of equity and justice, a fundamental change of circumstances may, under certain conditions, be invoked by a party as a ground for terminating the treaty'. ${ }^{4}$ Pursuant to this provision, a change of circumstances must be (1) of circumstances existing at the time of the treaty's conclusion, (2) fundamental, (3) not foreseen by the parties, (4) the existence of the circumstances must have constituted an essential basis for the consent of the parties to be bound by the treaty, and (5) the effect of the change must be to radically transform the scope of obligations still to be performed. ${ }^{5}$ The last three requirements indicate that the doctrine is to give effect to the parties' common intentions and shared expectations, which are being pursued with the conclusion of the treaty. Only when these shared expectations have been frustrated, may a party abrogate from the treaty. In the Gabcikovo-Nagymaros Project case, the International Court of Justice (ICJ) construed the doctrine in narrow terms. The negative and conditional wording of Article 62 VCLT was said to be a clear indication that the stability of treaty relations required the plea of fundamental change of circumstances to be applied only in exceptional cases. ${ }^{6}$ This has led a commentator to argue that the ICJ accords 'absolute priority to the stability of treaties, a principle which appears to trump the invocation of the doctrine of fundamental changes. ... Until the present, it has remained only a theoretical possibility for treaty terminations. ${ }^{\text {'7 }}$ Others have expressed the view that "[i]n spite of its theoretical importance, ... the practical relevance is minor' 8 and 'its recognition is nonetheless highly limited and the principle thus remains one of restricted application and of implicit applicability'. 9 On that basis, the doctrine has been described as 'a car that has never left the garage' ${ }^{10}$

Yet despite its asserted limited relevance, recent practice suggests that that the 'popular plaything of Realpolitiker from Bismarck to De Gaulle, and beyond'11 is returning with its old livery. The vital interest theory is being

\footnotetext{
4 ILC, 'Draft Articles on the Law of Treaties with Commentaries' YBILC (1966) vol II, 258 para 7. $\quad 5$ ibid 258 para $9 . \quad{ }^{6}$ Gabčikovo-Nagymaros Project (n 3) 65 [104].

7 M Fitzmaurice, 'Exceptional Circumstances and Treaty Commitments' in DB Hollis (ed), The Oxford Guide to Treaties (Oxford University Press 2012) 618.

${ }^{8}$ T Giegerich, 'Article 62-Fundamental Change of Circumstances' in O Dörr and K Schmalenbach (eds), Vienna Convention on the Law of Treaties - A Commentary (2nd edn, Springer 2018) 1146-7 para 7; C Binder, Die Grenzen der Vertragstreue im Völkerrecht (Springer 2013) 181.

9 MN Shaw and C Fournet, 'Article 62 Convention of 1969' in O Corten and P Klein (eds), The Vienna Conventions on the Law of Treaties: A Commentary (Oxford University Press 2011) vol 2, 1428 para 33 .

${ }_{10} \mathrm{M}$ Milanovic, 'Brexit, the Northern Irish Backstop, and Fundamental Change of Circumstances' EJIL:Talk! (18 March 2019)<https://www.ejiltalk.org/brexit-the-northern-irishbackstop-and-fundamental-change-of-circumstances/>.

11 J Klabbers, International Law (Cambridge University Press 2013) 64.
} 
invoked again. According to this theory, which is premised on the rights to selfpreservation and vital development of States, 'the changes of circumstances which must be regarded as fundamental or vital are those which imperil the existence or vital development of one of the parties'. ${ }^{12}$ This indicates a shift from the 'shared-expectations' approach that takes the intentions of all parties to a treaty into account, to an approach that puts more emphasis on the treaty's adverse effects on a single party. ${ }^{13}$ This phenomenon will be explored in four parts. The first part offers an overview of recent practice. The second part provides a broader historical contextualisation of the vital States' interests theory. The third part presents the stance expressed in the VCLT. Finally, the concluding remarks evaluate the significance of the recent practice and offer a tentative outlook for the future.

\section{RECENT STATE PRACTICE}

At first, practice on the doctrine after its codification in the VCLT was sparse. An exception was the end of the Cold War and the consequential reorganisations in many political systems in Europe and other parts of the world. This led to a political climate which induced a number of attempts to invoke the doctrine. ${ }^{14}$ Yet already in 1997, the ICJ's decision in the Gabcikovo-Nagymaros Project case brought a provisional end to this phase. Since the treaty in question provided for a joint investment programme, the Court held that the prevalent political and economical conditions in the former socialist States, which had subsequently emerged into a market economy, were not so closely linked to the object and purpose of the treaty that they had constituted an essential basis for the consent of the parties. ${ }^{15}$ Thus the ICJ determined whether the circumstances constituted an essential

\footnotetext{
12 Fisheries Jurisdiction (n 3) 20 [38].

13 The term 'shared-expectations' approach is adopted from OJ Lissitzyn, 'Treaties and Changed Circumstances (Rebus Sic Stantibus)’ (1967) 61(4) AJIL 895.

14 eg Hungary's suspension of two provisions of a treaty concluded with the German Democratic Republic (GDR) in 1989, by reference to Article 62 VCLT (see Streletz, Kessler and Krenz v Germany ECHR 2001-II 409, 419 para 17, 449 para 101); the GDR's invocation of art 62 VCLT in respect to a trade agreement with the Philippines. The Philippines' accepted the claim that the abolition of the GDR had constituted a fundamental change of circumstances within the contemplation of the doctrine ('Opinion No. 196 Series 1990-Effect of the unification of Germany on the trade agreement between the German Democratic Republic and the Republic of the Philippine' in K Akira, 'State Practice of Asian Countries in the Field of International Law' (1991) 1 Asian Yearbook of International Law 159, 177-8). Some commentators consider the Finnish President's promulgation, that the reference to Germany as a possible aggressor contained in the 1948 Treaty of Friendship, Co-operation and Mutual Assistance between Finland and the Soviet Union had become obsolete due to changes of circumstances, such as the relaxation of confrontation in Europe and the unification of Germany, to also represent an invocation of the rebus doctrine (O Dörr, 'Codifying and Developing Meta-Rules: The ILC and the Law of Treaties' (2006) 49 German Yearbook of International Law 129, 153. For the statement of the Finnish president, see 'Annex: Documents Relating to Germany's Unification' (1991) 51 Zeitschrift für ausländisches öffentliches Recht und Völkerrecht/Heidelberg Journal of International Law (HJIL) 494, 527-8). $\quad{ }^{15}$ Gabčikovo-Nagymaros Project (n 3) 64 [104].
} 
basis for the conclusion of the treaty (Article 62(1)(a) VCLT) by reference to the treaty's object and purpose. ${ }^{16}$ In addition, the ICJ also interpreted the condition of whether the change of circumstances had radically transformed the obligations to be performed under the treaty (Article 62(1)(b) VCLT) by reference to the treaty purpose, when stating that:

The changed circumstances advanced by Hungary are, in the Court's view, not of such a nature, either individually or collectively, that their effect would radically transform the extent of the obligations still to be performed in order to accomplish the Project [emphasis added]. ${ }^{17}$

This approach is in line with its earlier jurisprudence. In the Fisheries Jurisdiction case, the ICJ had clarified that the test does not ask whether the obligations to be performed under the treaty have become unduly burdensome for one of the parties. Rather, what it found decisive was whether the change of circumstances had increased the burden of the obligations to be executed to the extent of rendering the performance something essentially different from that originally undertaken' [emphasis added]. ${ }^{18}$ Accordingly, when applying the doctrine the ICJ uses the object and purpose of a treaty as a reference point. It gives thereby expression to the shared expectations of all treaty parties.

Despite the ICJ's adoption of the 'shared-expectations' approach, two different strands of arguments have recently emerged outside of the judicial context.

\section{A. Changes of Policy in the Domestic Realm}

The first kind of argument which has developed is the proposition that new constitutional arrangements in the domestic legal order of the invoking State may give rise to a fundamental change of circumstances that allows for the termination of treaties under international law.

\section{Poland's 1999 termination offive bilateral treaties on cultural and scientific cooperation}

Two years after the Gabčikovo-Nagymaros Project decision, in 1999, Poland sought to terminate five bilateral treaties on cultural and scientific cooperation $^{19}$ that had been concluded with the Union of Soviet Socialist

\footnotetext{
16 cf also Racke v Hauptzollamt Mainz (n 3) para 54, where the Court of Justice of the European Union determined whether the circumstances constituted an essential basis of the consent of the parties to be bound by the treaty in question by reference to the preamble and the article which expressly stipulated the treaty's object and purpose.

17 Gabčikovo-Nagymaros Project (n 3) 65 [104].

18 Fisheries Jurisdiction (n 3) 22 [43].

19 Agreement between the Polish People's Republic and the Union of Soviet Socialist Republics on Cultural and Scientific Cooperation of 14 December 1970; Agreement between the Government of the Polish People's Republic and the Government of the Mongolian People's Republic on
} 
Republics, the Mongolian People's Republic, the Laotian People's Republic, the Kampuchean People's Republic and the Republic of Cuba by invoking Article 62 VCLT. $^{20}$ Since the agreements included provisions that were designed to implement the socialist economic and social model, the radical changes in the political and economic system in Poland in 1989-1990, confirmed by the adoption of the new Constitution in 1997, were said to represent a fundamental change of circumstances. ${ }^{21}$ According to the Polish foreign ministry, Cambodia and Mongolia explicitly accepted these claims by notes of 14 December 1999 and 14 April 2000, respectively, while Laos, Russia, Ukraine and Belarus did not object. ${ }^{22}$ The exception was Cuba, which expressed the view that since the treaty in question had already expired in 1998 its termination was superfluous. ${ }^{23}$

For the purpose of assessing the practice, it should be noted that Poland had concluded the treaties with Mongolia, Laos, Russia, Ukraine and Belarus, before the States in question acceded to the VCLT, whereas Cambodia has still not ratified that Convention. Pursuant to Article 4 VCLT, the rules contained in the VCLT were, therefore, not applicable, save in so far as they are declaratory of customary international law. ${ }^{24}$ Since Article 62 VCLT reflects in many respects customary international law, ${ }^{25}$ it was nevertheless permissible to invoke this rule under the VCLT in relation to those States, which were parties to the Convention. Accordingly, the practice of Poland

Cultural and Scientific Cooperation of 18 February 1974; Agreement between the Government of the Polish People's Republic and the Government of the Laotian People's Democratic Republic on Cultural and Scientific Cooperation of 18 September 1979; Agreement between the Government of the Polish People's Republic and the Government of the Kampuchean People's Republic on Cultural and Scientific Cooperation of 6 August 1984; Agreement between the Government of the Polish People's Republic and the Government of the Republic of Cuba on Cultural, Educational and Scientific Cooperation of 17 June 1987.

${ }^{20}$ Minister for Foreign Affairs (W Bartoszewski), 'Oświdzenie Rządowe z dnia 30 maja 2001 r. o utracie mocy obowiązującej niektórych umów międzynarodowych’ 143 Dziennik Ustaw (Journal of Laws) $1602<$ http://prawo.sejm.gov.pl/isap.nsf/download.xsp/WDU20011431602/O/D20011602. pdf>.

21 Reply by the Secretary of State of the Ministry of Foreign Affairs (R Wiśniewski), 'Odpowiedź podsekretarza stanu w Ministerstwie Spraw Zagranicznych $-\mathrm{z}$ upoważnienia ministra-na interpelację posła Karola Karskiego w sprawie trybu wygáśnięcia umów międzynarodowych niezgodnych z Konstytucją RP (1508)' Sprawozdania stenograficzne z posiedzén Sejmu RP V kadencji, Annex to the 16th session of the Sejm on 25-27 April 2006, part 2, $418<$ http://orka. sejm.gov.pl/StenoInter5.nsf/0/C7EB348FABA0D170C1257DE8003FBD7B/\$file/

16_aneks_ksiazka_cz2_kopia.pdf $>$.

22 ibid 419; K Karski and T Kaminski, 'Effective Application of the Rule on Fundamental Change of Circumstances to Treaties Contravening the 1997 Polish Constitution' (2015) 17 International Community Law Review 68, 90-3.

23 ibid.

24 Armed Activities on the Territory of the Congo (New Application: 2002) (Democratic Republic of the Congo v Rwanda) (Jurisdiction and Admissibility: Judgment) [2006] ICJ Rep 6, 50 f. [125]; F Dopagne, 'Article 4 Convention of 1969' in O Corten and P Klein (n 9) 84-5 paras 15-18; K Schmalenbach, 'Article 4-Non-retroactivity of the present Convention' in O Dörr and K Schmalenbach (n 8) 89 para 1.

25 (n 3). 
and Mongolia can be considered to represent subsequent practice as a supplementary means of interpretation of Article 62 VCLT under Article 32 VCLT. ${ }^{26}$ The same applies to the omissions of Laos, Russia, Ukraine and Belarus to object. ${ }^{27}$ In the case of the treaty concluded with Cambodia, it is reasonable to assume that Poland invoked the doctrine under customary international law as reflected in the VCLT. ${ }^{28}$ As a result, the termination of this treaty represents State practice and expresses the opinio juris of Poland and Cambodia in this respect.

\section{Kenya's National Assembly resolution demanding withdrawal from the} Rome Statute

In 2013, Kenya's National Assembly approved a resolution, urging the government to withdraw from the Rome Statute ${ }^{29}$ as a change in the government was said to constitute a fundamental change of circumstances. ${ }^{30}$ A similar motion was adopted in the Senate. ${ }^{31}$ It has been argued that 'although it is unclear whether the motion's drafters invoked "fundamental changes of circumstances" deliberately, or inadvertently, such language in the motion' resonates 'with international treaty law'. 32

Concerned by these developments, the President of the Assembly of States Parties expressed the hope that Kenya would remain within the Rome Statute. But she also noted that in accordance with Article 127 of the Rome Statute a withdrawal would take effect only one year after formal notification

26 ILC, 'Conclusions on subsequent agreements and subsequent practice in relation to the interpretation of treaties, with commentaries', UN Doc A/73/10, conclusion 4(3) 27-37.

27 cf also WTO, EC-Customs Classification of Frozen Boneless Chicken Cuts-Report of the Appellate Body (12 September 2005) WT/DS269/AB/R and Corr.1, WT/DS286/AB/R and Corr.1 [272]: "the "lack of reaction" or silence by a particular treaty party may, in the light of attendant circumstances, be understood as acceptance of the practice of other treaty parties. Such situations may occur when a party that has not engaged in a practice has become or has been made aware of the practice of other parties (for example, by means of notification or by virtue of participation in a forum where it is discussed), but does not react to it.'

28 Reply by the Secretary of State of the Ministry of Foreign Affairs (n 21) 419.

29 (concluded 17 July 1998; entered into force 1 July 2002) 2187 UNTS 9.

30 Motion 105 of 5 September 2013, 'THAT, aware that the Republic of Kenya promulgated a new Constitution on 27th August, 2010 which has fundamental changes in the circumstances relating to the governance of the Republic; aware that the Republic conducted its general elections on the 4th of March, 2013 at which the President and Deputy President were lawfully elected in accordance with the Constitution of Kenya; this House resolves to introduce a Bill within the next thirty days to repeal the International Crimes Act (No.16 of 2008) and that the Government urgently undertakes measures to immediately withdraw from the Rome Statute of the International Criminal Court, adopted by the United Nations Diplomatic Conference of Plenipotentiaries on 17th July, 1998'.

31 'Submissions of the Government of Kenya on the Proposed Motion by Kenya's National Assembly and Senate to Withdraw Kenya from the Rome Statute' (15 October 2013) Doc No ICC-01/09-01/11.

${ }^{32}$ CC Jalloh, 'Kenya Should Reconsider Proposed Withdrawal from the ICC' EJIL:Talk! (18 September 2013) < https://www.ejiltalk.org/kenya-should-reconsider-proposed-withdrawal-fromthe-icc/>. 
and not affect any ongoing proceedings. ${ }^{33}$ Her remarks on the withdrawal clause stipulated in the Rome Statute suggest that she did not understand the motions to refer to the legal doctrine of fundamental change of circumstances. The International Criminal Court (ICC), however, appeared to at least consider the invocation of the doctrine possible. It requested the Kenyan government to clarify the legal implications of the legislative branch's endeavours. Thereupon, Kenya's Attorney General assured the Chamber of the government's intention 'to continue fully cooperating with Court'. He affirmed that 'should there be any material change of circumstances' the government would inform the ICC accordingly. ${ }^{34}$ Hence, the motions have not succeeded yet in convincing the government to leave the Court. As Kenya has neither ratified the VCLT nor has it become a party to its sister convention on treaties applicable to international organisations $^{35}$ the two motions cannot be treated as practice in the application of these Conventions. Nevertheless, the motions could represent evidence of State practice on the doctrine under customary international law. The inconsistency between the motions and the Attorney General's statements, as well as the fact that the government has not acted upon the legislature's endeavours, reduces, however, the weight that can be attached to this practice. ${ }^{36}$ But the jury is still out. In December 2016, President Uhuru Kenyatta proposed a reconsideration of the motions, as the ICC had 'become a tool of global power politics and not the justice it was built to dispense'. ${ }^{37}$

\section{The Chile-Ecuador BIT}

In 2010, the Constitutional Court of Ecuador found the bilateral investment treaty (BIT) between Ecuador and Chile to be incompatible with the Ecuadorian constitution as it provided for investor-State dispute settlement (ISDS). Since the new constitution was found to represent a fundamental change of circumstances affecting the performance of the BIT, the Court called upon the National Assembly to approve the termination of the treaty. ${ }^{38}$

33 'President Intelmann on Approval of Motion in the Parliament of Kenya to Start the Withdrawal Process from the Rome Statute' (6 September 2013) Doc ICC-ASP-20130906PR938<https://asp.icc-cpi.int/en_menus/asp/press\%20releases/Pages/pr938.aspx>.

34 Submissions of the Government of Kenya (n 31).

35 Vienna Convention on the Law of Treaties between States and International Organizations or between International Organizations (adopted 21 March 1986; not yet in force) UN Doc A/ CONF.129/15.

36 ILC, 'Conclusions on Identification of Customary International Law, with Commentaries', UN Doc A/73/10, 128 para 5.

37 Speech by President U Kenyatta during the 2016 Jamhuri Day Celebration (12 December 2016) <http://www.president.go.ke/2016/12/12/speech-by-his-excellency-hon-uhuru-kenyatta-cg-h-president-of-the-republic-of-kenya-and-commander-in-chief-of-the-defence-forces-duringthe-2016-jamhuri-day-celebrations-at-nyayo-national-stadiu/>.

38 Dictamen N. ${ }^{\circ}$ 038-10-DTI-CC, Caso N. ${ }^{\circ}$ 0010-TI, Corte Constitucional para el período de transición (11 November 2010) 23-6<https://portal.corteconstitucional.gob.ec/FichaRelatoria. aspx?numdocumento=038-10-DTI-CC $>$. 
A year later, a special committee of the National Assembly in charge of analysing the denunciation of a number BITs confirmed this view. ${ }^{39}$ Consequently, Ecuador's National Assembly approved the termination of the BIT in $2017 .{ }^{40}$ It should be noted, however, that when issuing the decree, the President relied primarily on the withdrawal clause in the investment treaty. ${ }^{41}$ This was presumably because of Chile's declared adherence to what it called a 'general principle of the immutability of treaties' - with the exception of withdrawal clauses stipulated in a treaty - and its reservation to Article 62(1) and (3) VCLT. Consequently, the invocation of the doctrine would have required a more complex justification than simply exercising the right of withdrawal set out in the BIT. If Chile had objected to the invocation of the doctrine, the state of unconstitutionality would have been further prolonged. But since Chile also accepted the denunciation in accordance with the withdrawal clause stipulated in the treaty, it is questionable whether the President's decree represents State practice on Article 62 VCLT. ${ }^{42}$ Moreover, although national courts decision may count as State practice ${ }^{43}$ and evidence of a State's acceptance as law (opinio juris), ${ }^{44}$ less weight can be accorded to the Constitutional Court judgment as it remains unenforced. ${ }^{45}$ Hence the question arises whether the court decision may still be used as a subsidiary means for the determination of the doctrine under customary international law. ${ }^{46}$ The value of Ecuador's Constitutional Court decision for this particular purpose depends primarily on its reception by other State organs. ${ }^{47}$ In this regard, it bears mentioning that the presidential decree also referred to the Constitutional Court judgment and to the report of the Commission for Comprehensive Audit of the Reciprocal Investment Treaties and the Investment International Arbitration System in Ecuador (CAITISA), which had been made public earlier that month. The CAITISA report proposed the termination of several

${ }^{39}$ Comisión Especializada Permanente No. 5 de Soberanía, Integración, Relaciones Internacionales y Seguridad Integral, 'Informe de Comisión sobre el pedido de aprobación de la denuncia del "Convenio Entre el Gobierno de la República de Chile para la Promoción y Protección Recíprocas de Inversiones"” (25 May 2011) <https://www.asambleanacional.gob.ec/es/ system/files/informe_comision_denuncia_convenio_ecuador_chile_promo_y_protec_inverciones_t. _68799_26-05-2011.pdf>.

40 Asamblea Nacional de la República del Ecuador, 'Resolución que aprueba la Denuncia del Convenio entre Ecuador y Chile para la Promoción y Protección Recíproca de Inversiones’ (3 May $2017)<$ https://www.asambleanacional.gob.ec/sites/default/files/den-conv-ecu-chi-03-05-2017. pdf $>$; J Jaramillo and C Muriel-Bedoya, 'Ecuadorian BITs' Termination Revisited: Behind the Scenes' Kluwer Arbitration Blog (26 May 2017) < http://arbitrationblog.kluwerarbitration.com/ 2017/05/26/ecuadorian-bits-termination-revisited-behind-scenes/>.

41 Presidential Decree No. 1403 of 16 May 2017, Registro Oficial, Suplemento N² 2, Lunes 29 de mayo de 2017, 18-9.

42 Note $N^{\circ} 140 / 17,5$ June 2017, cited in Foreign Ministry, 'Terminación del convenio entre el Gobierno de la República de Chile y el gobierno de la República del Ecuador para la promoción y protección recíproca de inversiones', decree 157, <https://www.leychile.cl/Navegar? idNorma $=1111878>$.

43 cf ILC, 'Conclusions on identification of customary international law, with commentaries' (n 36) conclusion 6(2), 133-4

${ }_{45}$ ibid conclusion $3(1), 128$ para $5 . \quad 46$ ibid conclusion $13(2), 149-50 . \quad 47$ ibid para 3. 
BITs in accordance with the clauses stipulated in the treaties, as this was considered to be the most effective option legally. In addition, it recommended justifying the decision on the grounds that the Constitutional Court of Ecuador had found the BITs to be incompatible with the new constitution, which represented an unforeseen and unpredictable event compared to the time when the BITs were concluded. This in turn amounted to a fundamental change of legal circumstances. It was argued that some of the investment treaties provided for objectives, such as the development and welfare of the host State, which had not been met, or shown to produce detrimental effects. On this note, the Commission expressed the view that maintaining these obligations meant sustaining commitments which were ruinous for the Ecuadorian people and contrary to the objectives of the treaties. ${ }^{48}$ Accordingly, the President's indirect reference to the doctrine can be seen as an auxiliary argument. Therefore, the President's reliance on the treaty's withdrawal clause does not contravene the Constitutional Court's judgment. Against this background, the judgment can be used as a subsidiary means for the determination of the doctrine under customary international law. ${ }^{49}$

\section{B. The Argument of Vital State Interests}

From the argument that Ecuador's new constitution constituted a fundamental change of circumstances, which allegedly made the reliance on the BIT ruinous for the Ecuadorian people, it is only a short step to an argument of vital State interests. For some States the values and norms protected by their constitutions are vital for their self-preservation and development. It is no wonder, therefore, that the second line of reasoning intended to justify a fundamental change of circumstances, is the one of vital State interests.

\section{The termination of the ABM-Treaty}

Certain commentators interpret the United States of America' (USA) termination of the Anti-Ballistic Missile Treaty (ABM Treaty) ${ }^{50}$ in 2001 as both an invocation of the termination clause enshrined in Article XV(2) ABM Treaty and an independent claim for a fundamental change of circumstances. ${ }^{51}$ In the diplomatic note sent to Russia, Belarus, Kazakhstan and the Ukraine, the US argued that since a number of State and non-State entities had acquired weapons of mass destruction, extraordinary events

\footnotetext{
48 CAITISA, 'Report' (May 2017) <http://www.caitisa.org/index.php/home/enlaces-deinteres $>99$.

49 ILC, 'Conclusions on identification of customary international law, with commentaries' (n 36) conclusion 13(2), 149-50.

50 Treaty on the limitation of anti-ballistic missile systems (signed 26 May 1972, entered into force 3 October 1972), 944 UNTS 13.

51 Fitzmaurice (n 7) 620-21.
} 
related to the subject matter of the treaty had occurred which had jeopardised the supreme interests of the US. ${ }^{52}$ In view of this, it decided to withdraw pursuant to Article XV(2) ABM Treaty - a decision that Russia accepted with regret, ${ }^{53}$ whereas the Ukraine thought it to be matter between Russia and the USA. ${ }^{54}$ As the argument in the diplomatic note mirrors the language of the termination clause and since, in accordance with this provision, the withdrawal was to take effect six months from the date of notice, it seems more convincing not to regard the termination of the ABM Treaty as practice on Article 62 VCLT. ${ }^{55}$ Nonetheless, the existence of Article XV(2) ABM Treaty and its invocation demonstrate that when it comes to questions of national security, States still seek to reserve a right to terminate a treaty when they consider that the treaty in question impedes vital State interests.

\section{The suspension of the PMDA}

In 2016 Russia suspended the Agreement Concerning the Management and Disposition of Plutonium Designated as No Longer Required for Defense Purposes and Related Cooperation (PMDA) ${ }^{56}$ by invoking 'a fundamental change of circumstances, or more precisely, aggressive anti-Russia tendencies' ${ }^{57}$ It justified the decision by referring to several hostile steps the US had taken with respect to Russia, such as the introduction of sanctions, the expansion of NATO military infrastructure in proximity to the Russian border, a policy of containment towards Russia and threats of terrorist attacks in Russian cities. ${ }^{58}$ From the perspective of international law, these acts,

\footnotetext{
52 Diplomatic Notes Sent to Russia, Belarus, Kazakhstan and the Ukraine on 13 December 2001 $<$ https://www.state.gov/documents/organization/16692.pdf $>$.

53 President W Putin, 'Statement Regarding the Decision of the Administration of the United States to Withdraw from the Antiballistic Missile Treaty of 1972' (13 December 2001) <http://en. kremlin.ru/events/president/transcripts/21444>.

54 'Rumsfeld To Ukrainians: WMD Threat Is Real' US Department of Defense Press Release (6 June 2001) <https://archive.defense.gov/news/newsarticle. aspx?id=45925>.

55 Similarly, S-I Lekkas and A Tzanakopoulos, 'Pacta sunt servanda versus flexibility in the suspension and termination of treaties' in CJ Tams, A Tzanakopoulos and A Zimmermann (eds), Research Handbook on the Law of Treaties (Edward Elgar Publishing 2014) 335, arguing that art $\mathrm{XV}(2)$ made any reliance on the doctrine superfluous; Giegerich (n 8) $1153 \mathrm{fn} 60$.

56 (signed at Moscow and Washington, 29 August 2000 and 1 September 2000, entered into force 13 July 2011).

57 K Daugirdas and JD Mortenson, 'Russia Suspends Bilateral Agreement with United States Disposal of Weapons-Grade Plutonium' (2017) 111(1) AJIL 181; Law suspending Russian-US Plutonium Management and Disposition Agreement (PMDA) signed 31 October $2016<\mathrm{http}$ ://en. kremlin.ru/acts/news/53167>; Foreign Minister Sergey Lavrov's interview with Channel One's Vremya weekly news and analysis programme, broadcast on Sunday, 9 October 2016, <http:// www.mid.ru/en/web/guest/meropriyatiya_s_uchastiem_ministra/-/asset_publisher/xK1BhB2bUjd3/ content/id/2494612>.

58 Draft law suspending the PMDA submitted to the State Duma, 3 October 2016, <http://en. kremlin.ru/acts/news/53009>; 'Comment by Foreign Minister S Lavrov on the publication of the presidential executive order to suspend the Russia-US plutonium management and disposition agreement', 3 October 2016, <http://www.mid.ru/en/web/guest/foreign_policy/news/-/asset_ publisher/cKNonkJE02Bw/content/id/2485001>.
} 
'resulting in a fundamental change in strategic stability', were claimed to constitute a fundamental change of circumstances within the meaning of the VCLT. ${ }^{59}$ Remarkably, Russia found it necessary to stress that the plutonium covered by the PMDA would remain outside the nuclear weapons sphere. ${ }^{60} \mathrm{It}$ thereby indicated that the plutonium was still not required for defence purposes and that Russia did not intend to breach the agreement. The foreign ministry explained that the point was rather to make the US realise that it was no longer possible to cooperate with other countries only in the spheres that would benefit it and to take measures to inflict massive damage to its partners in the other spheres. ${ }^{61}$ This explanation prompts the question whether Russia was not invoking changes outside the treaty, but which were stemming from other spheres. Regardless of whether or not one agrees with this description of the facts, the argument reveals an understanding of the doctrine that is linked to national security interests which need to be preserved and to damage which has to be averted by the State; in other words, the fundamental right of States to self-preservation which would be threatened, if the State party was to comply with the obligations set out in the treaty.

In its immediate response the US engaged with the argument of national security interests. Although regretting Russia's decision to suspend the treaty, it disputed only the assessment of facts, but did not object to the interpretation of the doctrine when arguing that it was in each side's national interest to continue the application of the treaty. ${ }^{62}$ It therefore appeared to have accepted that impeding national security interests could constitute a fundamental change of circumstances. Its latter assessments were more critical, however. In its 2017 and 2018 reports on 'Adherence to and Compliance With Arms Control, Nonproliferation, and Disarmament Agreements and Commitments', the Department of State asserted that while there was 'no indication the Russian Federation ... violated its obligations under the PMDA', it had not 'articulated a valid basis' for the suspension. ${ }^{63}$ Russia's foreign ministry reacted by reiterating its position that 'unilateral unfriendly actions of the United States, which have resulted in a fundamental change of circumstances compared to those existing at the time when the treaty was concluded ... created a threat to strategic stability' which permitted the suspension of the

59 ibid.

60 Draft law suspending the PMDA (n 61).

61 Comment by Foreign Minister S Lavrov (n 61); 'Russia's assessment of the US Department of State's Report on Adherence to and Compliance with Arms Control, Nonproliferation, and Disarmament Agreements and Commitments' (24 April 2018) <http://www.mid.ru/en/web/guest/ maps/us/-/asset_publisher/unVXBbj4Z6e8/content/id/3192916>.

${ }^{6}$ USA Department of State Press Release, Daily Press Briefing (3 October 2016) <https://20092017.state.gov/r/pa/prs/dpb/2016/10/262717.htm>; White House Press Release, Press Briefing by Press Secretary J Earnest (5 October 2016) < https://obamawhitehouse.archives.gov/the-press-office/ 2016/10/05/press-briefing-press-secretary-josh-earnest-1052016>; K Daugirdas and JD Mortenson (n 57) 187-8. $\quad 63$ The reports can be found at $<$ https://www.state.gov/adherence-to-andcompliance-with-arms-control-nonproliferation-and-disarmament-agreements-and-commitmentscompliance-report/>. 
treaty in accordance with Article 62 VCLT. ${ }^{64}$ Thereafter, the USA struck a more conciliatory tone. It clarified in its 2019 report that whether its potential concern with respect to Russia's intent to comply with PMDA had a basis could 'better be determined if and when the two sides re-engage under the PMDA'. ${ }^{65}$

As the US has not ratified the VCLT, it can be assumed that Russia's suspension represents State practice on the doctrine under customary international law. The US responses are more difficult to assess. The acknowledgement that the two parties are currently not engaging under the treaty suggests that the US has accepted the suspension of the PMDA. In this sense, it appears reasonable to regard its tacit acceptance as practice under the circumstances.

\section{The Danish emergency brake law}

Another recent example of such an approach comes from Scandinavia. Although a European Union (EU) Member State, Denmark enjoys a special position within the Dublin framework for the treatment of claims to international protection within the Union, as these regulations ${ }^{66}$ only apply to Denmark on an intergovernmental basis. ${ }^{67}$ On 15 March 2017, the Danish Minister for Immigration introduced a bill into Parliament, which provided for an emergency brake (nødbremse) in times of high influx of asylumseekers, according to which Denmark would not be obliged to follow the procedures of the EU's Dublin regulation. ${ }^{68}$ The bill was justified on the basis that under general international law any treaty was subject to the condition that the circumstances had not materially changed so that the performance of the treaty obligations had become seriously detrimental to a State party. In the case of unforeseen changes, which have the effect of making the fulfilment of the treaty obligations a serious threat to a State's existence or welfare, the treaty could be terminated on the basis of general emergency principles. On that note, the Minister referred to the clausula

64 'Russia's assessment of the US Department of State's Report on Adherence to and Compliance with Arms Control, Nonproliferation, and Disarmament Agreements and Commitments' (24 April 2018) <http://www.mid.ru/en/web/guest/maps/us/-/asset_publisher/ unVXBbj4Z6e8/content/id/3192916>. 65 (n 66).

${ }^{66}$ Council Regulation (EC) $343 / 2003$ of 18 February 2003 establishing the criteria and mechanisms for determining the Member State responsible for examining an asylum application lodged in one of the Member States by a third-country national, OJ L50/1; EU Regulation (EU) $604 / 2013$ of 26 June 2013 establishing the criteria and mechanisms for determining the Member State responsible for examining an application for international protection lodged in one of the Member States by a third-country national or a stateless person, OJ L180/31.

${ }^{67}$ Council Decision 2006/188/EC of 21 February 2006 on the conclusion of the Agreement between the European Community and the Kingdom of Denmark extending to Denmark the provisions of Council Regulation (EC) 343/2003 and Council Regulation (EC) 2725/2000, OJ L66/37.

${ }_{68}$ Minister for Immigration and Integration (I Støjberg), 'Forslag til Lov om ændring af udlændingeloven' (March 2017) L 153 <https://www.ft.dk/ripdf/samling/20161/lovforslag/1153/ 20161_1153_som_fremsat.pdf>. 
rebus sic stantibus under international law. ${ }^{69}$ This argument is difficult to reconcile with the 'shared-expectations' approach. Despite not being applicable to Denmark, ${ }^{70}$ it can hardly be claimed that the Kingdom was unaware of Article 64(2) of the Treaty establishing the European Community ${ }^{71}$ - nowadays Article $78(3)$ TFEU $^{72}$ — which provided for measures that could be adopted in the case 'of one or more Member States being confronted with an emergency situation characterised by a sudden inflow of nationals of third countries'. Therefore, high influxes of asylumseekers cannot be considered to represent an unforeseeable event. ${ }^{73}$

The argument corresponds better to the vital interests theory. The reference to threats to the existence and welfare of the State are explicit allusions to the fundamental rights of States to the vital development and self-preservation. Despite criticism by the United Nations Commissioner for Refugees, ${ }^{74}$ the Danish Parliament passed the Act on 11 May 2017. ${ }^{75}$ Although Germanypresumably the most relevant neighbouring State in this particular contexthas been informed, it has so far abstained from taking a stance on the validity of the legal argument. ${ }^{76}$ The EU has likewise refrained from expressing its legal opinion on the matter. An explanation might be that reform of the Dublin process is currently under negotiation, which is supposed to include a corrective allocation mechanism in those cases where a Member State is confronted with a disproportionate number of applications for international protection. ${ }^{77}$ But not too much weight ought to be attached to the EU's silence. After all, the Act has not yet been applied in practice. ${ }^{78}$ In any case, the enactment of the domestic law and the justification provided by the minister represent evidence of State practice ${ }^{79}$ and of Denmark's opinio juris on the doctrine under customary international law. ${ }^{80}$

\footnotetext{
69 Forslag til Lov om ændring af udlændingeloven (n 72) 7, section 2.4.1.

70 Protocol (No 22) to the Treaty on the Functioning of the EU (TFEU) on the position of Denmark, OJ C326/299. $\quad 71$ OJ C340/173. 72 OJ C326/47.

73 cf also the reasoning in Case C-646/16 Jafari [2017] ECR, paras 93-101.

74 UNHCR Regional Representation for Northern Europe, 'UNHCR Observations on the proposed amendments to the Danish Aliens legislation' (22 February 2017) <http://www. refworld.org/pdfid/58b02f384.pdf>.

75 'Lov om ændring af udlændingeloven (Mulighed for i en krisesituation at afvise asylansøgere ved grænsen)', adopted on third reading, 11 May $2017<\mathrm{https}: / / w w w . f t . d k /$ ripdf/samling/20161/ lovforslag/1153/20161_1153_som_vedtaget.pdf $>$.

76 'Regierung will Asylrecht weiter verschärfen' Zeit Online (30 August 2016) <https://www. zeit.de/politik/ausland/2016-08/daenemark-fluechtlinge-fluechtlingspolitik-grenze-asylpolitik>.

77 Commission, 'Proposal for a regulation of the European Parliament and of the Council on establishing the criteria and mechanisms for determining the Member State responsible for examining an application for international protection lodged in one of the Member States by a third-country national or a stateless person' (recast) COM (2016) 270 final, art 34.

78 But see the proposal to activate the emergency brake: 'Forslag til folketingsbeslutning om aktivering af nødbremsen til afvisning af asylansøgere ved grænsen' (21 March 2018) Beslutningsforslag Nr. B 106 <https:/www.ft.dk/ripdf/samling/20171/beslutningsforslag/b106/ 20171_b106_som_fremsat.pdf>.

79 ILC, 'Conclusions on identification of customary international law, with commentaries' (n 36) 134 para 5.

80 ibid 141 paras $4-5$.
} 


\section{THE VITAL INTERESTS THEORY}

The full significance of the practice presented in the previous section becomes clear in the light of the broader historical context. The argument of vital State interests, with its focus on the burden placed on an individual treaty party rather than on the common intentions of all the parties to the treaty in question, is not a new phenomenon. Since its earliest days, the doctrine has often been linked to such arguments. Hugo Grotius, for example, found the doctrine to be applicable if the performance of the treaty obligations led to the ruin of the State. ${ }^{81}$

At the end of the nineteenth century and the beginning of the twentieth century academics and practitioners refined this theory. An influential view at that time combined the concept with a theory on fundamental rights of States. These fundamental rights were considered to be the only vital interests which allowed for the termination of treaties. As a result, a State could abrogate a treaty if compliance with the obligations forced a State to sacrifice its inherent rights to vital development or self-preservation. This theory is usually attributed to the Austrian public international lawyer Georg Jellinek, ${ }^{82}$ who described it in terms of a right of necessity in cases where the self-preservation of a State was imperilled. ${ }^{83}$ Other renowned proponents included Erich Kaufmann, who developed his theory in his 1911 book Das Wesen des Völkerrechts und die clausula rebus sic stantibus, ${ }^{84}$ and Lassa Oppenheim, as can be seen in the first three editions of his famous textbook International Law: A Treatise. ${ }^{85}$ The former Solicitor of the US Department of State, ${ }^{86}$ Lester H. Woosley, ${ }^{87}$ and the Chinese scholar Ching-Lin Hsia ${ }^{88}$ can also be counted amongst those who linked the doctrine to the vital development of States and the right to existence. ${ }^{89}$ Therefore, it does not come as a surprise that in the Fisheries Jurisdictions case this understanding was presented as the traditional view:

${ }^{81}$ SC Neff (ed) and H Grotius, On the Law of War and Peace (Cambridge University Press 2012) 229.

82 A Vamvoukos, Termination of Treaties in International Law: The Doctrines of Rebus Sic Stantibus and Desuetude (Oxford University Press 1985) 15-21.

${ }^{83}$ G Jellinek, Die Rechtliche Natur der Staatenverträge (Hölder 1880) 62; but cf already E de Vattel, Le Droit des gens (1758) II, Ch XII section 170, Ch XVII section 296,

${ }^{84}$ E Kaufmann, Das Wesen des Völkerrechts und die clausula rebus sic stantibus (2nd edn, Scientia 1964) 204.

${ }^{85}$ L Oppenheim, International Law: A Treatise (3rd edn, Longmans 1920) vol I, 689-90.

${ }^{86}$ Nowadays called 'Legal Adviser of the Department of State' (Act of Congress of 23 February 1931, P.L. 71-715; 46 Stat. 1214).

${ }^{87}$ LH Woolsey, 'The Unilateral Termination of Treaties' (1926) 20(2) AJIL 346, 349-50.

${ }^{88}$ C-1 Hsia, 'Treaty Relations between China and Great Britain' (1924) 8 Chinese Social \& Political Science Review 88, 107-8.

89 cf also Federal Tribunal (Switzerland), Judgment of 17 February 1882, 8 BGE 44 - Lucerne v Aargau, 57-8; L Olivi, 'D'un cas controversé de cessation de la force obligatoire des traits internationaux' (1891) 23 Revue de Droit International et de Législation Comparée 590, 608; L le Fur, État fédéral er Confédération d'État (Marchal et Billard 1896) 537-8; F Despagnet, Cours de droit international public (4th edn, L Larose and L Tenina 1910) 708-9; D Dyzenhaus (ed) and H Heller, Sovereignty (Oxford University Press 2019) 176-7. 
The invocation by Iceland of its 'vital interests', which were not made the subject of an express reservation to the acceptance of the jurisdictional obligation under the 1961 Exchange of Notes, must be interpreted, in the context of the assertion of changed circumstances, as an indication by Iceland of the reason why it regards as fundamental the changes which in its view have taken place in previously existing fishing techniques. This interpretation would correspond to the traditional view that the changes of circumstances which must be regarded as fundamental or vital are those which imperil the existence or vital development of one of the parties. ${ }^{90}$

The danger of the vital interests theory becomes apparent, however, when taking Hersch Lauterpacht's observations into account. In The Function of Law in the International Community, he found that 'on those rare occasions on which treaties were broken under colour of the doctrine rebus sic stantibus it was obvious that no question of self-preservation arose unless, indeed, every change in the constellation of power enabling the State to disregard with impunity an onerous obligation be regarded as a material change of conditions implied in the treaty'. ${ }^{91}$ What this statement demonstrates is twofold. On the one hand, the vital interests theory, although formulating a limit to the binding force of treaties, had the side effect of constraining the doctrine by stipulating a high threshold that had barely been met in practice. As James Brierly pointed out, 'an unforeseen change of such magnitude as to imperil the existence of one of the parties is so rare as to be negligible'. ${ }^{92}$ But on the other hand, as long as States were not inhibited from determining on a subjective basis what exactly their vital interests were, the theory posed the risk of abusive assessments on part of the invoking States. ${ }^{93}$ From a doctrinal perspective then, the invocation of subjectively determined vital interests in connection with the doctrine asserted 'that the rule pacta sunt servanda does not apply to States with the same cogency as it applies to individuals, for the simple reason that they are States, and that their interests cannot be subjected to an obligation existing independent of their own will'. ${ }^{94}$ As a consequence, the binding character of international treaties could be negated in the domain of vital interests. ${ }^{95}$

90 Fisheries Jurisdiction (n 3) 20 [38].

91 H Lauterpacht, The Function of Law in the International Community (Oxford University Press 1933) 278-9.

92 JL Brierly, 'Some Considerations on the Obsolescence of Treaties' (1925) 11 Transactions of the Grotius Society $11,17$.

93 JP Bullington, "International Treaties and the Clause 'Rebus Sic Stantibus" (1927) 76 UPaLRev 153, 166; G Del Vecchio, 'La Société des Nations au point de vue de la philosophie du droit international' (1931) 38 Recueil des Cours (RdC) 541, 576-7; G Haraszti, 'Treaties and the Fundamental Change of Circumstances' (1975) 146 RdC 1, 50-1; CR Blaser, Die clausula rebus sic stantibus im Völkerrecht (Dike 2012) 68.

95 R Kolb, The Law of Treaties (Edward Elgar 2017) 227. 


\section{THE APPROACH OF THE VCLT}

Back in 1944, Brierly thought this self-judging character of the vital interests theory had its roots 'in the insecurity of the existing order, in the fact that every state has hitherto had to make its own defence the prime consideration of all its policies'. But 'if a world security order in which states had confidence could be established, . . . the most difficult kind of vital interests would begin to lose their urgency'. ${ }^{96}$ Hence the sophisticated collective security system established in the UN Charter system of international law after World War II provided an opportunity to reassess the cogency of the vital interests theory - an opportunity which was embraced with the conclusion of the VCLT.

\section{A. Changes of Policy in the Domestic Realm}

In his second report on the law of treaties, Special Rapporteur Sir Humphrey Waldock proposed inserting a paragraph stipulating that a change in the policies of the State seeking to terminate a treaty, or in its motives or attitude with respect to a treaty, could not constitute a fundamental change of circumstances. ${ }^{97}$ Other members of the ILC, however, 'while not dissenting from the view that mere changes of policy on the part of a government cannot normally be invoked as bringing the principle into operation, felt that it would be going too far to state that a change of policy could never in any circumstances be invoked as a ground for terminating a treaty' and 'instanced a treaty of alliance as a possible case where a radical change of political alignment by the government of a country might make it unacceptable, from the point of view of both parties, to continue with the treaty' ${ }^{98}$ As a result, Article 62 VCLT does not contain a paragraph excluding explicitly the invocation of changes of policy.

Nevertheless, the ILC recognise the dangers of abusive attempts to terminate treaties on the basis merely of a change of policy. ${ }^{99}$ The example of treaties of alliances, the majority adduced, suggests that in those exceptional cases where a change of policy is considered to be sufficient, the change must be accepted by all parties to the treaty. ${ }^{100}$ In addition, the change must not be caused by the party invoking the doctrine. It may not be invoked as a ground for terminating a treaty, if it is the result of a breach by the invoking State of obligations owed to the other party (Article 62(2)(b) VCLT). These obligations include the performance of the

96 JL Brierly, 'Vital Interests and the Law' (1944) 21 BYBIL 51, 56.

97 Special Rapporteur Sir Humphrey Waldock, 'Second report on the law of treaties' YBILC (1963) vol II, 80, 84-5 para 15.

98 ILC, 'Draft Articles on the Law of Treaties with commentaries' (n 4) 259 para 10.

99 ibid.

100 ILC, 'Draft Articles on the Law of Treaties with commentaries' (n 4) 259 para 10. 
treaty in good faith (Article 26 VCLT). ${ }^{101}$ Moreover, the doctrine cannot be interpreted in a way that conflicts with the principle of State continuity and so a change of government, or even in the system of government, will usually not qualify as a fundamental change of circumstances. ${ }^{102}$ In this vein, Australia expressed the view during the negotiations of the VCLT that if 'a change of political attitude made the treaty unacceptable to both parties, they should obviously agree to terminate it', but 'a change in government policy should in no event be invoked as a ground for unilaterally terminating a treaty. ${ }^{\prime} 03$

\section{B. Vital State Interests}

When explaining the rationale behind the doctrine, the ILC acknowledged that as a result of a fundamental change of circumstances the provisions of a treaty might come to place an undue burden on one of the parties. If international law was not to offer any legal means for terminating the treaty then this could impose a serious strain on the relations between the States concerned, which might ultimately impel States to take action outside the law. ${ }^{104}$ This 'undue burden' approach - which can be seen as a less radical version of the vital interests theory-has found expression in the requirement that the effect of the change must be to radically transform the scope of obligations still to be performed under the treaty. ${ }^{105}$ But this requirement is not a sufficient criterion on its own. It constitutes just one of the five requirements of Article 62 VCLT. The change must also be (1) of circumstances existing at the time of the conclusion of the treaty, (2) fundamental, (3) not foreseen by the parties and (4) the existence of those circumstances must have constituted an essential basis of the consent of the parties to be bound by the treaty. The reference to the essential basis of the consent of the parties demonstrates that the ILC dismissed any theory that linked the doctrine to any general changes quite outside the treaty. ${ }^{106}$

What is more, the ILC decided not to use the term 'rebus sic stantibus' in order to avoid any doctrinal implications. Instead, it referred to the rule as the doctrine of 'fundamental change of circumstances', ${ }^{107}$ which was supposed to be 'an objective rule of law by which, on grounds of equity and justice, a fundamental change of circumstances may, under certain conditions, be invoked by a party as a ground for terminating the treaty'. ${ }^{108}$ This approach,

101 ME Villiger, Commentary on the 1969 Vienna Convention on the Law of Treaties (Martinus Nijhoff 2009) 777 para 23.

102 Shaw and Fournet (n 9) 1429-30.

103 UN Conference on the Law of Treaties (UNCLT) 'Summary records of the plenary meetings and of the meetings of the Committee of the Whole' (First Session, Vienna, 26 March-24 May1968) (10 May 1968) UN Doc A/CONF.39/11, 372 para 23.

104 ILC, 'Draft Articles on the Law of Treaties with commentaries' (n 4) 258 para 6.

105 Lissitzyn (n 13) 913.

106 ILC, 'Draft Articles on the Law of Treaties with commentaries' (n 4) 259 para 10.

107 ibid 258 para 7. 
now enshrined in Article 62 VCLT and in the ILC commentaries, represents the dominant view today. ${ }^{109}$ A proposal to integrate the vital interests theory into the VCLT by replacing the 'undue-burden' approach with the stricter standard that the change must have the effect of imperilling the State's existence was rejected at the Vienna Conference on the Law of Treaties. The attempt by Belarus to confine the doctrine to cases "when a State found it completely impossible to perform a treaty, or where a treaty conflicted with its most vital interests', ${ }^{110}$ did not gain support. As a result, the doctrine as codified in the VCLT represents a rejection of the proposition that imperilling a State's vital interests could by itself constitute a fundamental change of circumstances.

\section{CONCLUDING REMARKS}

Notwithstanding contrary statements in the literature, the preceding discussion illustrates that the doctrine of rebus sic stantibus has indeed practical relevance today. Recent practice suggests, however, that States have returned to interpreting the doctrine by invoking changes in the domestic realm or vital State interests. The subsequent practice of Poland, Mongolia, Laos, Russia, Ukraine and Belarus in the application of Article 62 VCLT as supplementary means of interpretation under Article 32 VCLT, as well as the State practices of Poland and Cambodia concerning the doctrine as a matter of customary international law, demonstrate a willingness to regard changes in the constitutions of the invoking States as being a ground for the termination of treaties in accordance with the doctrine. The judgment of Ecuador's Constitutional Court represents a subsidiary means for the determination of the doctrine under customary international law to the same effect. The motions approved by the Kenyan Parliament point in a similar direction, although they may have limited legal value. Moreover, the practice of the US and Russia in connection with PDMA, as well as the practice of Denmark with respect to the Dublin regulations, reveals an understanding that links the doctrine to vital State interests. Argument of vital interests and the ones underlying the invocation of changes in the domestic sphere are kindred arguments. Some States consider that the values and norms enshrined in their constitutions reflect their respective vital interests.

These practices indicate a departure from the 'shared-expectations' approach which the ILC and the ICJ had adopted. They give priority to the adverse effects of the changes on the vital interests of one of parties, rather than to the frustrated common intentions of all the parties to treaty. Instead of confining the doctrine

\footnotetext{
109 A Poch de Caviedes, 'De la clause « rebus sic stantibus » à la clause de révision dans les conventions internationales' (1966) 118 RdC 108, 166-9; M Koskenniemi, From Apology to Utopia (Cambridge University Press 2005) 344; CR Blaser (n 93) 519; Kolb (n 95) 227-8; Giegerich (n 8) 1145-6; Maritime Delimitation in the Area between Greenland and Jan Mayen (Judgment) [1993] ICJ Rep 38, Separate Opinion by Judge Weeramantry 217 [17].

110 UNCLT (n 107) 379 para 7.
} 
to changes which frustrate the object and purpose of the treaty, they open the door for changes which are not related to the object of the treaty as such. This makes it more difficult to predict which changes may constitute a fundamental change of circumstances and opens the door for subjective determinations by the invoking State. It is this line of reasoning that led Lauterpacht to state that "[f]rom Spinoza to modern deniers of international law, the doctrine rebus sic stantibus has been appealed to not only as a consequence, but also as the very proof of the States' independence of law'.111 Yet the promise behind every treaty demands good faith performance: Pacta sunt servanda. A treaty is worth nothing if it is not kept and if it cannot be relied on. Compromising the sanctity of treaties compromises international law's ability to regulate the behaviour of its legal subjects.

The invocation of the doctrine in conjunction with vital State interests has to be seen against the backdrop of a broader tendency to contest rules of international law on the basis of arguments premised on vital interests and other sovereignty-related concerns. First, national security exceptions and derogation clauses in time of emergency have recently gained prominence in practice. ${ }^{112}$ The nexus between these clauses and the doctrine is remarkable. The WTO Dispute Panel has only just found that the security exception stipulated in Article XXI(b) (iii) General Agreement on Tariffs and Trade ${ }^{113}$ 'acknowledges that a war or other emergency in international relations involves a fundamental change of circumstances which radically alters the factual matrix in which the WTO-consistency of the measures at issue is to be evaluated'. ${ }^{114}$ Second, arguments based on constitutional identity that seek to pose limits to the binding force of international legal rules can be found in the reasoning of numerous constitutional court decisions. ${ }^{115}$ These types of arguments display a kinship to vital interests and States' rights. ${ }^{116}$ Third, the current backlash against international adjudication is also often accompanied

111 Lauterpacht (n 91) 279.

112 T Voon, 'The Security Exception In WTO Law: Entering a New Era' (2019) 113 AJIL Unbound 45, 46-7; M Polzin, 'Der verrechtlichte Ausnahmezustand: Art. 15 EMRK und die Rolle des Europäischen Gerichtshofs für Menschenrechte' (2018) 78(3) HJIL 635, 636-7; C Cai, 'Enforcing a New National Security - China's National Security Law and International Law' (2017) 10(1) Journal of East Asia and International Law 65, 74-6.

113 (concluded 30 October 1947, entered into force 1 January 1948) 55 UNTS 187.

114 WTO, Russia-Measures Concerning Traffic in Transit-Report of the Panel (29 April 2019) WT/DS512/R [7.108].

115 cf F Fabbrini and A Sajó, 'The Dangers of Constitutional Identity' (2018) 25(4) European Law Journal 457; H Krieger and A Zimmermann, 'Sentenza 238/2014 of the Italian Constitutional Court and the International Rule of Law' (2018) KFG Working Paper Series No 29, Berlin Potsdam Research Group 'The International Rule of Law - Rise or Decline?' 26-8.

116 cf HP Aust, 'Fundamental Rights of States: Constitutional Law in Disguise' (2015) 4(3) CJICL $521,540-4$, who found the German Constitutional Court's reference in its Lisbon Treaty decision (BVerfG, Judgment of the Second Senate of 30 June 2009, 2 BvE 2/08, paras 226-31, <https://www. bundesverfassungsgericht.de/SharedDocs/Entscheidungen/EN/2009/06/es20090630_2bve000208en. $\mathrm{html}>$ ) to the 'right to self-determination of the German people in the form of Germany's sovereignty 
with the assertion that international courts and tribunals tread upon the vital interests of States in the maintenance of their sovereignty. ${ }^{117}$ On a related note, the topical critique on international investment law and ISDS tends to draw on the language of fundamental States' rights. ${ }^{118}$ It thus seems too early to assume that arguments premised on fundamental States' rights to selfpreservation and vital development have become a thing of the past. ${ }^{119}$

This raises the question of whether it is still possible to arrest this development or whether the vital interests theory is becoming an undisputed element of the doctrine with which the international community needs to come to terms. The practice of Russia and the US in connection with the PMDA, for example, could go either way. The arguments could be rephrased in terms of the 'shared-expectations' approach. But they could also be formulated in a way so as to replace the 'undue burden' approach ${ }^{120}$ by the stricter requirement that the change must have the effect of imperilling the State's existence - without necessarily affecting the other requirements set out in Article 62 VCLT. Yet it is also conceivable that further examples of practice may adjust or undermine the other requirements as well. ${ }^{121}$ It remains to be seen whether future practice and the arguments concerning the doctrine affect our understanding of it, and whether the vital interests theory will subvert the sanctity of treaties.

More cases are on the horizon. Other actors have also shown an inclination to invoke the doctrine. In the Philippines, the chairperson of the Committee on Justice has referred to the doctrine when seeking to justify a potential reimposition of the death penalty in disregard of international human rights obligations. ${ }^{122}$ In the United Kingdom, the Attorney General has recently suggested during a debate in Parliament that a sovereign State had 'the right

under international law' and the requirement of 'independence from an external will precisely for its constitutional foundations' to evoke connotations of Kaufmann's theory on vital interests.

${ }_{117} \mathrm{C}$ McLachlan, 'The Assault on International Adjudication and the Limits of Withdrawal' (2019) 68(3) ICLQ 499, 513-4.

118 cf A Kulick, 'Investment Arbitration, Investment Treaty Interpretation, and Democracy' (2015) 4(2) CJICL 441; E Guntrip, 'Self-Determination and Foreign Direct Investment: Reimagining Sovereignty in International Investment Law' (2016) 65(4) ICLQ 829.

119 See, for example, Legality of the Threat or Use of Nuclear Weapons (Advisory Opinion) [1996] ICJ Rep 226, 263 [96-7].

${ }_{120}$ Expressed in the requirement that the effect of the change must have been to render the performance of the obligations something essentially different from that originally undertaken.

${ }^{121} \mathrm{cf}$, for example, the reasoning of the Iran-US Claims Tribunal in Questech Inc. v Ministry of National Defense of Iran (Award No 191-59-1, 25 September 1985, 9 IRAN-USCTR 107) 123, in respect to the requirement of unforeseeability. In order to justify the legal validity of Iran's termination of the contract on grounds of the principle of changed circumstances, the tribunal observed that "the Claimant could have been aware that such changes in this particular area were more foreseeable than in other fields of contractual relations' and that the 'Claimant could therefore not expect that the Contract would remain unaffected by changes in such a highly sensitive military domain'.

${ }_{122}$ Plenary Proceedings of the 17th Congress' (14 February 2017) 4(70) Congressional Record (1st regular session of the House of Representatives), $8 \mathrm{ff}<$ http://www.congress.gov.ph/legisdocs/ congrec/17th/1st/17C1RS-VOL4REC70-20170214.pdf>. 
to withdraw if a treaty is no longer compatible with its fundamental interests or, to put it a different way, if fundamental circumstances have changed'. ${ }^{123}$ In his opinion, 'some fundamental political change in Northern Ireland or some fundamental change of circumstance going to the essential basis of the agreement' could provide a unilateral right to withdraw from the Protocol on Northern Ireland, which had been negotiated in the connection with the Agreement on the Withdrawal of the United Kingdom from the EU and the European Atomic Energy Community. ${ }^{124}$ Even the UN Special Rapporteur on the rights of indigenous peoples has lately proposed that in 'order to suspend or terminate an international investment agreement that affects indigenous peoples' rights', States could invoke Article 62 VCLT 'in relation to a fundamental change in circumstances, such as the recognition of indigenous peoples within their borders', as a complementary measure necessary to mitigate the impact of international investment agreements. ${ }^{125}$

International law is formed through assertion and reaction. It is therefore to be hoped that States and other relevant actors will keep the long-term impacts in mind when seeking to justify the invocation of the doctrine in future cases or when elaborating on the arguments already made. The same applies to those who are called upon to react. On the one hand, viable responses to the vital interests theory will have to take the State practice and sovereignty concerns seriously, but on the other hand, they must not undermine the international rule of law. It remains in the vital interests of the international community to interpret the doctrine of rebus sic stantibus in a way that preserves the existence of international law and does not imperil its development.

123 HC Deb 12 March 2019, vol 656, col 198.

125 UN Human Rights Council, 'Report of the Special Rapporteur on the rights of indigenous peoples' (2016) UN Doc A/HRC/33/42, 23 para 107. 